\title{
Medische docenten: tijd voor kwaliteit
}

P.M.J. Stuyt

\section{Samenvatting}

Inleiding: Medische curricula hebben de afgelopen jaren grote veranderingen ondergaan: het onderwijs is kleinschalig en studentgeoriënteerd. Dit stelt nieuwe eisen aan docenten en geeft een impuls aan docententrainingen. Ophoging van de numerus fixus vraagt om verdere uitbreiding van het docentenaantal.

Probleemstelling: Het aantrekken van voldoende en voldoende gekwalificeerde medische docenten wordt bemoeilijkt door de ondergeschikte positie van onderwijs ten opzichte van onderzoek en patiëntenzorg. Het toenemend tekort aan artsen maakt het probleem nog groter. Hoe komen we aan de medische docenten om kwantitatief en kwalitatief te kunnen voldoen aan de behoefte aan artsen? Hoe dienen universitaire medische centra (UMC's) op dit punt beleid te maken?

Maatregelen: Voor UMC's dienen medisch onderwijs en opleiding dezelfde prioriteit te hebben als onderzoek en patiëntenzorg. Door onderwijsactiviteiten te registreren en te evalueren wordt onderwijs zichtbaar. Hieraan kan de honorering op individueel en afdelingsniveau worden gekoppeld. Carrièrekansen op grond van onderwijsprestaties dienen helder gemaakt te worden door het formuleren van criteria. Voor jonge stafleden wordt het zo aantrekkelijk zich te profileren in onderwijs. Omgekeerd kan van artsen met een topstafbenoeming worden verwacht dat zij zichtbaar participeren in het onderwijs. Door activiteiten in onderwijs, onderzoek en patiëntenzorg af te laten wisselen kunnen artsen een nieuwe uitdaging in hun werk vinden. Ook artsen in de geaffilieerde ziekenhuizen kunnen op deze wijze een grotere rol in het onderwijs spelen.

Conclusie: Met bovenstaande maatregelen kunnen UMC's expliciet beleid maken ter versterking van medisch onderwijs en opleiding teneinde het kwalitatief en kwantitatief niveau van de toekomstige artsengeneratie veilig te stellen. (Stuyt PMJ. Medische docenten: tijd voor kwaliteit. Tijdschrift voor Medisch Onderwijs 2002;21(4):183-187.)

\section{Inleiding}

Medische curricula hebben de afgelopen jaren grote veranderingen ondergaan. Onderwijskundige inzichten en de steeds maar uitdijende medische kennis hebben, mede onder druk van de visitaties in het kader van de kwaliteitszorg, bij alle universitaire medische centra (UMC's) tot de invoering van kleinschalig en studentgeoriënteerd onderwijs geleid. Er is ruim tijd voor zelfstudie en tijdens het contactonderwijs hebben docenten een andere rol dan voorheen: hun activiteiten zijn meer gericht op facilitering van het leerproces dan op kennisoverdracht. Dit stelt andere eisen aan docenten. curriculumveranderingen hebben dan ook een impuls aan docententrainingen en -professionalisering gegeven.

Modern medisch onderwijs maakt gebruik van de klinische context, ook vroeg in het curriculum. Contacten met patiënten en gebruik van klinische problematiek zijn van groot belang voor het opdoen en onthouden van medische kennis. Dit vraagt om toenemende betrokkenheid van 
medici bij het onderwijs. Daarnaast vragen de verdere ophoging van de numerus fixus voor de studie geneeskunde en de vergrijzing van het huidige docentencorps om uitbreiding van het docentenaantal, met name uit de klinische afdelingen.

In dit artikel wordt ingegaan op de problemen die worden ondervonden bij het bereiken van voldoende kwaliteit en kwantiteit in het medisch docentencorps. Vervolgens worden handreikingen gedaan hoe deze problemen kunnen worden aangepakt.

\section{Probleemstelling}

Onderwijs heeft nog steeds een ondergeschikte positie ten opzichte van wetenschappelijk onderzoek en patiëntenzorg. Ook door het toenemend tekort aan artsen wordt het steeds moeilijker medische docenten te vinden. Hoe komen we in de komende jaren aan de docenten om voldoende goede artsen op te kunnen leiden? Hoe dient een UMC op dit punt beleid te maken?

Recent heeft Markert samengevat waaraan men een goede medische docent kan herkennen. ${ }^{1}$ Genoemd worden ambitie en plezier in onderwijs, oriëntatie op studenten, studenten leren de stof te begrijpen in plaats van pure kennisoverdracht, zelf niet te veel praten, maar juist de studenten laten praten, enthousiasme tonen en geïnteresseerd zijn in studenten, werken aan verbetering van leermethodes, bij studenten de intrinsieke motivatie op basis van nieuwsgierigheid prikkelen in plaats van de extrinsieke op basis van toetsing en, tot slot, het expliciet vrijmaken van tijd voor de onderwijstaak. Opvallend is dat deskundigheid in de eigen discipline niet genoemd wordt. Vanzelfsprekend is deze deskundigheid nodig, maar om een goede docent te zijn, zijn de eerder genoemde vaardigheden belangrijker.
Voor een individuele arts heeft onderwijs onaantrekkelijke kanten. Er is tijdsdruk door andere taken, met name de patiëntenzorg. Wetenschappelijk onderzoek wordt beloond met een zichtbare verbetering van het curriculum vitae (publicatielijst) en met congresbezoek, veelal in het buitenland, waar een leuke vakantie aan vast te knopen valt. In de patiëntenzorg krijgt men regelmatig attenties van dankbare patiënten en familie. Goed onderwijs geven is moeilijk en vraagt tijd om zich voor te bereiden, zowel in algemene zin als op het specifieke onderwijsonderdeel waarvoor men gevraagd is. Ook kan een docent zich afvragen of hij of zij wel de geëigende persoon is om onderwijs te geven: is het de taak van de seniorstaf, hoogleraar of hoofddocent, of juist van de jongste assistent?

Regelmatig staan er in medische tijdschriften advertenties voor een onderwijsmedewerker/AGNIO (assistentgeneeskundige-niet-in-opleiding). Als onderwijstaken worden genoemd: het geven van vaardigheidsonderwijs, het functioneren als begeleider van co-assistenten en het functioneren als tutor van medisch studenten. Moeten we dit beschouwen als geëigende taken voor een jonge, net afgestudeerde arts-assistent, die niet eens in opleiding is? Zijn dit eigenlijk niet de taken die toebehoren aan professioneel daartoe opgeleide docenten? Het is onthutsend te moeten constateren dat slechts de helft van de hoogleraren in het UMC Sint Radboud een substantiële bijdrage levert aan het onderwijs. ${ }^{2}$ In andere UMC's en internationaal is het beeld overigens niet anders. ${ }^{3}$ Ook de participatie van nieuw benoemde hoogleraren is niet groter. Weliswaar worden in toenemende mate hoogleraren benoemd op speciale onderwijsleerstoelen, doch daar staat tegenover dat het merendeel van de benoemingen geschiedt op basis van onderzoeksprestaties. 
Blokcoördinatoren hebben moeite artsen te vinden die bereid zijn om tijd en energie in onderwijs te steken.

Afdelingen en divisies aarzelen hoe groot hun bijdrage aan het onderwijs moet zijn. Enerzijds is participatie van belang gezien de academische status van de afdeling en de profilering van de discipline, anderzijds ervaart men de vergoeding, zeker bij uitbreiding van onderwijstaken, als te gering.

De centrale onderwijsorganisatie staat voor de taak meer docenten te vinden, gezien de ophoging van de numerus fixus. Er is behoefte en noodzaak om docenten te trainen, maar tegelijkertijd is er bij docenten een toenemende weerstand om tijd voor onderwijs vrij te maken, mede gezien de druk in de patiëntenzorg. In geaffilieerde ziekenhuizen voelt men dat de coassistentenbegeleiding specifieke onderwijskwaliteiten met bijbehorende training en tijdsinvestering vraagt, terwijl de affiliatievergoeding daarmee niet in overeenstemming is.

\section{Maatregelen}

Op alle niveaus in de onderwijsorganisatie moet expliciet beleid worden gemaakt om aan bovenstaande problemen het hoofd te kunnen bieden.

Voor een $U M C$ dienen medisch onderwijs en opleiding evenveel prioriteit te hebben als patiëntenzorg en onderzoek. Immers, de UMC's hebben als enige de bevoegdheid om artsen op te leiden. Het opleiden van medisch studenten kan niet aan anderen worden overgedragen. Als er keuzes moeten worden gemaakt tussen onderwijs en patiëntenzorg, is het wel mogelijk afspraken te maken met regionale instellingen over verschuivingen in patiëntenstromen.

Door onderwijsactiviteiten te registreren en te evalueren wordt onderwijs zichtbaar, in kwaliteit en kwantiteit. Hieraan kan de honorering op individueel niveau (bijvoorbeeld aanstellingsrang, toelage) en afdelingsniveau (budget/formatie) direct worden gekoppeld. Carrièrekansen op grond van onderwijsprestaties dienen helder te zijn. Dit kan bereikt worden door duidelijke criteria te formuleren. Deze criteria hebben betrekking op gevolgde trainingen en geleverde prestaties. Studentenevaluaties leveren daar een bijdrage aan. Enige relativering is hier op zijn plaats, omdat contactonderwijs beperkt is in tijd en aan kleine groepen studenten gegeven wordt. Bovendien wordt van docenten in hun huidige rol geen voordrachtskunst meer verlangd. De nadruk ligt op het geven van feedback.

Op afdelingsniveau moeten de middelen direct aan de taken gekoppeld worden door periodieke herijking van het onderwijsmiddelenverdeelmodel. Doordat de besteding van de werkplaatsgelden met de nodige mistigheid is omgeven, wordt binnen afdelingen nogal eens vergeten dat ter facilitering van de onderwijs- en onderzoekstaak een grote som geld in de UMC's binnenkomt. De ophoging van de numerus fixus biedt de mogelijkheid om over de besteding van de extra werkplaatsgelden minder geheimzinnig te doen en zo de afdelingen te motiveren om voor de uitbreiding van de onderwijstaak en de verhoging van de onderwijskwaliteit op te komen.

Medisch onderwijs vraagt centrale sturing en centrale onderwijsfuncties zijn van vitaal belang met het oog op de onderwijskwaliteit. Voor deze centrale onderwijsfuncties is een expliciet loopbaanbeleid noodzakelijk. Het is wenselijk benoemingen in onderwijsfuncties een tijdelijk karakter te geven en periodiek na te gaan of herbenoeming terecht en wenselijk is of dat anderen een kans moeten krijgen.

Op afdelingsniveau moet bij de opbouw van de staf en werving van medewerkers 
rekening gehouden worden met de onderwijstaak. In dit verband dient de topstaf van een afdeling zijn verantwoordelijkheid ten aanzien van onderwijs niet te ontlopen. Als de hoogleraar niet het voorbeeld geeft om onderwijs serieus te nemen, is de juniorstaf evenmin geneigd dit te doen. Door in het loopbaanbeleid van artsen in een UMC onderwijs als criterium mee te nemen, wordt het voor jonge stafleden aantrekkelijk zich te profileren in onderwijs. Omgekeerd kan van artsen met een topstafbenoeming (hoogleraar, academisch hoofdspecialist of universitair hoofddocent) worden verwacht dat zij zichtbaar participeren in het onderwijs; het dient dan ook een vast onderwerp in het jaargesprek te zijn, nu deze ook voor de topstaf gebruikelijk zijn. Door activiteiten in onderwijs, onderzoek en patiëntenzorg af te wisselen kunnen artsen een nieuwe uitdaging in hun werk vinden.

Arts-assistenten volgen meestal zelf een opleiding (tot specialist) en zijn tegelijk weer docent voor co-assistenten. Zij dienen dan ook een van de doelgroepen bij de docententraining te vormen. Inmiddels is in het UMC Utrecht een stage klinische onderwijskunde in de internistenopleiding van start gegaan. ${ }^{4}$ De deelname aan docententrainingen kan worden vergroot door onderwijs in het carrièrebeleid mee te nemen en door als UMC de professionalisering te thematiseren en er geld voor vrij te maken. Mede gezien het positieve effect op de kwaliteit van de patiëntenzorg zijn docententrainingen inmiddels door huisartsen erkend als geaccrediteerde scholing en nascholing. Dit verdient navolging door de andere beroepsgroepen.

Ook voor individuele artsen bieden bovenstaande maatregelen kansen hun carrière uit te stippelen en desgewenst het accent voor kortere of langere tijd op onderwijs te leggen. Soms is het nuttig uit te leggen wat in een modern curriculum van docenten gevraagd wordt. Niet iedereen is ermee bekend dat het merendeel van het initiatief en de inspanning bij de student zelf ligt. Dit vergt een andere voorbereiding en tijdsinvestering van de docent. Coaching van jonge docenten door ervaren stafleden is een buitengewoon effectieve wijze van docententraining.

In de geaffilieerde instellingen zijn talloze artsen betrokken bij onderwijs, die ondanks de druk in de patiëntenzorg meestal zeer gemotiveerd zijn. De UMC's moeten hun cursus docententraining op maat ter plekke beschikbaar stellen. Er zijn artsen in de geaffilieerde instellingen die in bepaalde fasen van hun carrière het accent naar onderwijs willen verschuiven. Door onderwijstaken in de affiliatie en in het UMC te combineren en disciplineoverstijgend te maken is het mogelijk tot academische aanstellingen te komen. Grote geaffilieerde instellingen die een meer dan gemiddelde onderwijsinspanning leveren, opteren voor de titel 'teaching hospital'. In landelijk verband moet er bij de overheid op gewezen worden dat een adequate honorering voor medisch onderwijs noodzakelijk is. De moderne medische curricula, met leerdoelen ontleend aan het Raamplan 2001 en gekoppeld aan leertrajecten met bijbehorende docentenrollen, bieden de mogelijkheid hierover een inhoudelijke discussie met de overheid te voeren, opdat er een reële vergoeding voor medisch onderwijs en opleiding komt. Dan kan tijd worden vrijgemaakt om de kwaliteit van docenten en die van het onderwijs te optimaliseren.

\section{Conclusie}

De UMC's staan voor de opgave om de enorme aantallen medisch studenten volgens moderne onderwijsconcepten een 
hoogwaardige wetenschappelijke opleiding tot arts te bieden. Dit is alleen mogelijk door onderwijs en opleiding dezelfde prioriteit te geven als onderzoek en patiëntenzorg, zowel in tijd als in geld. De overheid moet de UMC's hiertoe de middelen geven en blijven geven. De UMC's moeten deze middelen, inclusief de werkplaatsgelden, zichtbaar en daadwerkelijk voor onderwijs inzetten. Individuele artsen moeten ook hun verantwoordelijkheid nemen en tijd steken in onderwijs en de kwaliteit leveren die de toekomstige artsengeneratie nodig heeft. Met bovenstaande maatregelen kunnen UMC's expliciet beleid maken ter versterking van medisch onderwijs en opleiding teneinde het kwalitatief en kwantitatief niveau van de toekomstige artsengeneratie veilig te stellen.

\section{Literatuur}

1. Markert RJ. What makes a good teacher? Lessons from teaching medical students. Acad Med 2001;76:808-10.

2. Stuyt PMJ. Medisch onderwijs: kwaliteit in balans [inaugurele rede]. Nijmegen; 2001.

3. Levinson W, Rubenstein A. Mission critical - integrating clinician-educators into academic medical centers. N Engl J Med 1999;341:840-3.

4. Borleffs JCC, Erkelens DW, Stuyt PMJ. Oog voor de toekomst. Het geneeskundeonderwijs in de 21e eeuw. Medisch Contact 2001;56:144-7.

De auteur:

Prof. dr. P.M.J. Stuyt, internist, directeur onderwijsinstituut, UMC St Radboud, Nijmegen.

Correspondentieadres:

Prof. dr. P.M.J. Stuyt, internist, 541 algemeen interne geneeskunde, UMC Sint Radboud, Postbus 9101, 6500 HB Nijmegen, tel. 024 3618819, fax 0243541734 , p.stuyt@aig.azn.nl.

\section{Summary}

Introduction: In recent years medical curricula have undergone dramatic changes: education has become student oriented and most teaching takes place in small groups. As a result medical teachers are faced with new challenges. This provides a fresh impetus for teacher training courses. Increasing student numbers call for more medical teachers.

Problem: Qualified teachers are hard to recruit because of the subordinate position of teaching versus research and patient care. The increasing shortage of medical doctors augments the problem. How can we recruit the medical teachers we will need in the coming years to meet the demand for more doctors, both quantitatively and qualitatively? What policies should a university medical centre (UMC) pursue on this point?

Measures: UMCs should give equal priority to medical education, research and patient care. By registration and evaluation of teaching activities educational efforts can be made visible and linked to rewards both at individual and departmental level. Explicitly formulated criteria can clarify the connection between educational activities and career opportunities. In this way it becomes attractive for junior staff members to try to distinguish themselves through educational achievement. Conversely, senior staff should be expected to make a visible contribution to teaching. By alternating between teaching, research and patient care doctors can discover new challenges in their work. Doctors from affiliated hospitals can also play a larger role in medical education.

Conclusion: The above-mentioned policy measures can be used by UMCs to strengthen the position of medical education and thus guarantee the qualitative and quantitative level of the next generation of medical doctors. (Stuyt PMJ. Medical teachers: time for quality. Dutch Journal of Medical Education 2002;21(4):183-187.) 